\title{
PENGEMBANGAN PERANGKAT PEMBELAJARAN TEOREMA PYTHAGORAS DENGAN PENDEKATAN IDEAL BERBANTUAN GEOGEBRA
}

\author{
Wulan Fitriyani ${ }^{1)}$, Sugiman ${ }^{2)}$ \\ SMP Negeri 3 Pati $^{1)}$, Universitas Negeri Yogyakarta ${ }^{2)}$ \\ wfitriyani83@gmail.com ${ }^{1)}$, sugiman_uny@gmail.com ${ }^{2)}$
}

\begin{abstract}
Abstrak
Penelitian ini bertujuan untuk mendeskripsikan tingkat kevalidan, kepraktisan, dan keefektifan hasil pengembangan perangkat pembelajaran Teorema Pythagoras dengan pendekatan IDEAL berbantuan GeoGebra ditinjau dari prestasi dan motivasi belajar matematika siswa. Penelitian ini merupakan penelitian dan pengembangan dengan model 4-D dari Thiagarajan, Semmel, \& Semmel. Tahapannya meliputi define, design, develop, dan disseminate. Penelitian dilakukan pada siswa kelas VIII SMP Negeri 3 Pati dengan satu kelas uji coba yang dipilih secara acak. Data dikumpulkan melalui tes kemampuan penyelesaian masalah (TKPM), angket motivasi, lembar validasi, dan lembar penilaian guru dan siswa. Instrumen TKPM digunakan untuk mengetahui prestasi dan daya serap siswa, angket motivasi untuk mengetahui skor motivasi belajar matematika siswa, lembar validasi untuk mengetahui kevalidan produk yang dikembangkan, dan lembar penilaian oleh guru dan siswa untuk mengetahui tingkat kepraktisan produk yang dikembangkan. Data yang diperoleh dianalisis secara deskriptif kuantitatif dan kualitatif. Hasil penelitian menunjukkan bahwa: (1) produk perangkat pembelajaran yang dikembangkan dalam penelitian ini berupa silabus, RPP, dan LKS sangat valid; (2) produk perangkat pembelajaran yang dikembangkan sangat praktis bagi guru dan siswa; dan (3) produk perangkat pembelajaran telah memenuhi kriteria sangat efektif ditinjau dari prestasi dan motivasi belajar siswa, sebanyak 83,33\% siswa berhasil mencapai KKM yang ditetapkan dan 87,5\% siswa memiliki motivasi belajar matematika yang tinggi.
\end{abstract}

Kata Kunci: Teorema Pythagoras, IDEAL, GeoGebra

\section{DEVELOPING A PYTHAGOREAN THEOREM TEACHING KIT USING THE GEOGEBRA-AIDED IDEAL APPROACH}

\begin{abstract}
This research aims to describe the validity, the practicality, and the effectiveness of the developed product of a Pythagorean Theorem teaching kit using the GeoGebra-aided IDEAL approach in terms of students' achievement and motivation. This study is a research and development, with the 4-D development model of Thiagarajan, Semmel, \& Semmel. The stages of this research included define, design, develop, and disseminate. The study was conducted at the eighth grade students of SMP Negeri 3 Pati with one tryout class who were randomly selected. The techniques of data collection in this study included a problem solving ability test (TKPM), motivation questionnaire, validation sheet, and sheets of teacher and student assessment. The instruments were TKPM to determine the students' achievement, motivation questionnaire to determine the score of students' motivation in mathematics learning, validation sheets to determine the validity of the developed product, and assessment sheets by teacher and students to determine the level of practicality of the developed products. The data were analyzed by descriptive quantitative and qualitatively. The result of the study show that: (1) the developed teaching kit consist of syllabi, lesson plans, and worksheet which have gone through the validation process by experts and they are found to be very valid; (2) the practicality of the developed product is achieved through the analysis of the teacher and student assessment; and (3) the developed product is effective in terms of students' achievement and learning motivation.
\end{abstract}

Keywords: Pythagorean Theorem, IDEAL, GeoGebra 


\section{PENDAHULUAN}

Matematika memerlukan keterampilan intelektual tingkat tinggi atau abstraksi tingkat tinggi dari pemikiran manusia yang kreatif (Chambers, 2008, p.7; Suneetha, Rao, \& Rao, 2011, p.23). Ada beberapa alasan akan pentingnya matematika dalam kurikulum sekolah, yaitu: matematika merupakan dasar semua ilmu pengetahuan; berhubungan dengan kehidupan manusia; membangun sikap logis; memberikan kepastian cara berpikir (Suneetha \& Rao, 2011, pp. 71-72). Oleh karena itu, sudah sewajarnya matematika menjadi ilmu dasar bagi ilmu lain yang wajib dipelajari.

Penyelesaian masalah atau problem solving merupakan salah satu kemampuan yang harus dikuasai siswa dalam belajar matematika. Oleh karena itu, guru sebagai fasilitator bagi siswa dalam pembelajaran hendaknya mengembangkan dan melatih kemampuan problem solving siswa secara terprogram sesuai standar proses pembelajaran. Secara esensi, problem solving ditunjukkan sebagai sebuah orientasi dan keterampilan yang dipelajari, yang menunjukkan bahwa siswa dapat mensintesis informasi dan secara trial and error berusaha mencari solusi dari masalah tersebut (Henton, Baden, \& Kieren, 1979, p.62). Di samping itu, penyelesaian masalah merupakan salah satu tingkatan dalam keterampilan berpikir tingkat tinggi (Brookhart, 2010, p.3).

Bransford \& Stein (1993, p.7) menyatakan bahwa masalah terjadi ketika ada kesenjangan antara kenyataan awal dan tujuan yang ingin dicapai dan belum tersedianya solusi bagi problem solver, dan merupakan situasi yang dihadapi siswa yang segera memerlukan penyelesaian (Posamentier \& Krulik, 2009, p.2) atau keadaan yang didalamnya terdapat pertanyaan terbuka (open question) yang menantang seseorang secara intelektual ingin segera menjawab pertanyaan tersebut dengan metode/prosedur/ algoritma dan yang lainnya yang dimilikinya (Blum \& Niss, 1991, p.37). Siswa yang tidak tertantang tidak akan tertarik untuk mengerjakan soal penyelesaian masalah. Inilah yang menunjukkan pentingnya tantangan dalam suatu masalah untuk memotivasi para siswa. Schraw, Dunkle, \& Bendixen (1995, p.523) menyatakan bahwa masalah well-defined dibatasi dalam dua cara, yaitu (1) hanya ada solusi yang benar yang dapat ditentukan secara pasti; (2) terdapat jaminan prosedur yang sesuai dalam menentukan solusi, berlawanan dengan masalah ill-defined yang mempunyai banyak solusi atau bahkan tidak mempunyai solusi karena tidak ada jaminan prosedur dalam menentukan solusi. Kirkley (2003, p.8) menjelaskan bahwa karakteristik masalah well-defined biasanya strategi penyelesaiannya dapat ditebak, hanya ada satu jawaban benar, dan semua informasi yang diberikan merupakan bagian dari masalah. Sedangkan masalah ill-defined mempunyai karakteristik solusi tidak dapat didefinisikan dengan baik atau tidak dapat ditebak, dan membutuhkan informasi lain yang harus dikumpulkan.

Empat kategori aktivitas penyelesaian masalah yang diperlukan dalam usaha menganalisis masalah adalah pengetahuan, strategi penyelesaian masalah yang dikenal sebagai strategi heuristic, penerimaan dan pengaturan diri sebagai sebuah aspek metakognisi, sistem kepercayaan individu (mengenai dirinya dan pengalaman matematikanya) dalam menyelesaikan masalah (Schoenfeld, 2013, p.11). Posamentier \& Krulik (2009: p.6) membagi penyelesaian masalah menjadi sembilan strategi, yaitu mengorganisasikan data (membuat daftar dan tabel), penebakan dan pengujian secara cerdas, menyelesaikan masalah yang ekuivalen menjadi lebih sederhana, bertindak, melihat kembali, menemukan pola, berpikir logis, membuat gambar, dan mengadopsi beberapa sudut pandang yang berbeda. Sedangkan Schoenfeld (1980: p.795) menyatakan bahwa strategi heuristic merupakan sebuah teknik umum yang membantu dalam memahami dan menyelesaikan masalah. Lebih lanjut dijelaskan bahwa heuristic merupakan strategi dan teknik dalam membuat kemajuan pada masalah asing dan tidak standar dengan penyelesaian masalah yang efektif, yang meliputi menggambar bentuk, mengubahnya ke dalam notasi yang sesuai, mengekplorasi masalah yang berkaitan, merumuskan kembali masalah dan melihatnya kembali, pengujian dan verifikasi prosedur (Schoenfeld, 1985: p.15). Pada buku klasiknya How to Solve It, George Polya menuliskan empat langkah pedoman agar berhasil menyelesaikan masalah. Yaitu memahami masalah, merencanakan bagaimana menyelesaikan masalah, melaksanakan rencana penyelesaian masalah, melihat (mengecek) kembali (2004: p.6).

Bruner menyatakan bahwa kunci keterlibatan siswa dalam penyelesaian masalah adalah pengembangan terhadap perencanaan pembelajaran yang fokus terhadap masalah-masalah yang terjadi saat ini (Henton, Baden, \& Kieren, 1979: p.62). Desain pembelajaran yang berbeda 
diperlukan dalam rangka menyelesaikan masalah yang diberikan. Salah satu pendekatan dalam penyelesaian masalah adalah IDEAL yang dirancang untuk membantu dalam mengidentifikasi dan memahami bagian-bagian yang berbeda dalam penyelesaian masalah, yang setiap hurufnya merupakan singkatan dari proses dalam menyelesaikan masalah (Bransford \& Stein, 1993, p.19). IDEAL adalah singkatan dari $I$ Identify problem, D-Define goal, E-Explore possible strategies, A-anticipate outcomes and act, L-look back dan learn (Bransford \& Stein, 1993: p.2). Hasil penelitian yang dilakukan oleh Nunn \& Kimberley (2000: p.305) menunjuk-kan bahwa IDEAL sebagai salah satu proses pendekatan penyelesaian masalah merupakan sebuah metode aktif yang menyediakan kerangka yang bermanfaat untuk membantu pendidik dalam menyelesaikan permasalahan yang kompleks yang sesuai dengan kondisi siswa sekarang.

Salah satu Standar Kompetensi (SK) dalam Matematika kelas VIII adalah menggunakan Teorema Pythagoras dalam pemecahan masalah. Teorema Pythagoras merupakan salah satu materi esensial dalam matematika, karena merupakan materi prasyarat dalam mempelajari materimateri yang berkaitan dengan Geometri, baik datar maupun ruang dalam kelas VIII dan kelas IX. Oleh karena itu, Teorema Pythagoras harus benar-benar dipahami dan dimengerti oleh siswa. Diharapkan siswa dapat menerapkannya dalam penyelesaian masalah pada materi yang relevan. Teorema Pythagoras di dalamnya berlaku bahwa pada setiap sembarang segitiga sikusiku, jika digambarkan persegi-persegi pada ketiga sisinya, maka luas persegi pada hipotenusa (sisi di depan sudut siku-siku) akan sama dengan jumlah luas daerah persegi pada dua sisi yang lain (Skemp, 1971: p.216; Gantert, 2007: p.301; Bailey et al, 2006: p.479).

Berdasarkan analisis Ulangan Harian Bersama I semester 1 dan data hasil Ulangan Akhir Semester Gasal tahun pelajaran 2012/2013 diperoleh data bahwa daya serap kemampuan siswa kelas VIII SMP Negeri 3 Pati yang seluruhnya berjumlah delapan kelas, pada standar kompetensi Teorema Pythagoras masih di bawah rata-rata, yaitu $56,6 \%$ dan $66 \%$. Demikian juga dengan data Ulangan Akhir Semester yang diadakan oleh Dirjen RSBI, daya serap pada SK ini hanya mencapai $68 \%$. Hal ini perlu mendapatkan perhatian yang serius, supaya pada tahun pelajaran mendatang, daya serap siswa pada SK ini mengalami peningkatan dan prestasi belajar siswa juga akan meningkat. Selain itu dari hasil yang diperoleh dengan penyebaran angket tentang motivasi kepada 75 siswa di SMP Negeri 3 Pati, disimpulkan bahwa motivasi belajar matematika siswa masih perlu ditingkatkan. Sedangkan berdasarkan diskusi yang dilakukan terhadap lima guru matematika yang ada di SMP Negeri 3 Pati tentang kendala yang dihadapi ketika membelajarkan siswa pada materi Teorema Pythagoras adalah seringnya terjadi kesalahan konsep siswa dalam memahami Teorema Pythagoras dan menerapkan rumusnya dalam soal-soal penyelesaian masalah.

Motivasi belajar merupakan dorongan seorang siswa untuk bertindak (belajar) karena adanya rangsangan baik dari dalam maupun luar yang mempengaruhi proses belajarnya. Motivasi dipengaruhi oleh faktor internal yang meliputi kepuasan, ketertarikan belajar, tantangan dan juga faktor eksternal yang meliputi adanya pujian, penghargaan, hadiah, hukuman, maupun adanya hak istimewa (Alderman, 2004: p.247; Schunk, 2012: p.531). Prestasi belajar didefinisikan sebagai suatu hasil yang telah diperoleh siswa atau dipelajarinya yang dalam mencapai tujuan yang ditetapkan. Senada dengan hal tersebut, menurut pemerintah, prestasi adalah hasil yang telah dicapai dari yang telah dilakukan atau dikerjakan. Semakin baik penguasaan siswa dalam proses belajar maka semakin baik prestasi yang akan dicapai (Gage \& Berliner, 1984: p.82).

Salah satu dampak kemajuan teknologi dalam pembelajaran matematika adalah terciptanya software-software yang sangat membantu dan mempermudah penyelesaian masalah Matematika. Salah satu dari software tersebut adalah Cabri 3D. Melalui Cabri 3D, visualisasi materi geometri bisa lebih mudah dipahami, karena dilengkapi dengan fasilitas untuk pengerjaan pengeplotan dan animasi untuk grafik pada dimensi dua dan dimensi tiga. Namun, visualisasi yang dihasilkan kurang dinamis. Software lainnya adalah GeoGebra, yang lebih dinamis jika diterapkan pada materi geometri. Iranzo \& Fortuny (2011, p.91) dalam penelitiannya mengenai pengaruh GeoGebra dalam strategi pemecahan masalah, menyatakan bahwa penggunaan GeoGebra membantu siswa dalam meningkatkan pemahaman matematika melalui alternatif penyelesaian masalah yang mungkin dan membantu kesulitan belajar matematika siswa. Pemanfaatan software GeoGebra ini, diharapkan para siswa dapat membangun pengetahuannya tentang materi Pythagoras pada 
Standar Kompetensi (SK) menggunakan Teorema Pythagoras dalam pemecahan masalah.

Belum tersedianya perangkat pembelajaran dengan pendekatan IDEAL berbantuan software GeoGebra sampai saat ini di sekolah membuat guru belum menerapkannya. Hal ini dapat disimpulkan berdasarkan angket yang disebarkan pada beberapa guru matematika di Kabupaten Pati. Perangkat pembelajaran yang dikembangkan dapat memudahkan siswa dalam memahami materi pelajaran, sehingga kemampuan penyelesaian masalah siswa meningkat.

Berdasarkan uraian sebelumnya, pada penelitian ini akan dikembangkan suatu perangkat pembelajaran matematika di SMP dengan pendekatan IDEAL berbantuan software GeoGebra pada SK "menggunakan Teorema Pythagoras dalam pemecahan masalah". Perangkat yang dikembangkan diharapkan valid sehingga dapat digunakan dalam kelas. Penggunaan perangkat ini diharapkan mampu memfasilitasi siswa selama pembelajaran sehingga motivasi dan hasil belajar matematikanya dapat meningkat sesuai dengan yang diharapkan. Khususnya dalam hal kemampuan penyelesaian masalah pada SK Menggunakan Teorema Pythagoras dalam pemecahan masalah.

Permasalahan yang dirumuskan dalam penelitian ini adalah seberapa valid, praktis, dan efektif perangkat pembelajaran yang berupa silabus, RPP, dan LKS pada materi Teorema Pythagoras yang dikembangkan dengan menggunakan pendekatan IDEAL berbantuan GeoGebra ditinjau dari prestasi dan motivasi belajar siswa. Adapun tujuan penelitian pengembangan ini adalah mendeskripsikan tingkat kevalidan, kepraktisan, dan keefektifan hasil pengembangan perangkat pembelajaran Teorema Pythagoras dengan pendekatan IDEAL berbantuan GeoGebra jika ditinjau dari prestasi dan motivasi belajar siswa.

\section{METODE}

Penelitian ini termasuk jenis research and development yaitu pengembangan perangkat pembelajaran Teorema Pythagoras dengan pendekatan IDEAL berbantuan GeoGebra. Perangkat yang dikembangkan meliputi silabus, RPP, dan LKS. Model pengembangan pembelajaran untuk menghasilkan perangkat pembelajaran yang digunakan dalam penelitian ini adalah model 4-D dari Thiagarajan, Semmel, \& Semmel.

Penelitian dilakukan di SMP Negeri 3 Pati yang berlokasi di Jalan Kolonel Sugiyono 17
Pati, pada bulan November sampai dengan Desember 2014. Adapun subjek coba dalam penelitian ini adalah siswa kelas VIII SMP Negeri 3 Pati dengan satu kelas uji coba yang dipilih secara acak.

Model pengembangan perangkat pembelajaran yang digunakan dalam penelitian ini diadaptasi dari model pengembangan pembelajaran Thiagarajan, Semmel, \& Semmel yang dikenal dengan model 4-D (define, design, develop, and disseminate). Model 4-D yang digunakan dimodifikasi pada bagian disseminate (penyebaran). Pada tahap penyebaran, hanya dilakukan sebatas publikasi perangkat kepada teman sejawat melalui forum MGMP Matematika Kabupaten Pati, publikasi melalui blog pribadi peneliti.

Tahap pertama (define) dalam penelitian ini meliputi analisis terhadap masalah dan alternatif terhadap pengembangan perangkat, analisis karakteristik siswa, dan analisis materi Pythagoras. Selanjutnya, menentukan indikator pembelajaran dan tujuan pembelajaran. Tahap design dilakukan pembuatan kisi-kisi dan penyusunan soal TKPM. Rancangan awal perangkat pembelajaran disusun dengan menerapkan pendekatan IDEAL dan aplikasi GeoGebra dalam pelaksanaan pembelajaran. Tahapan develop, dilakukan validasi ahli terhadap perangkat yang dikembangkan. Setelah perangkat dinyatakan valid, dilakukan uji coba terbatas, dan uji coba lapangan. Hasil revisi akhir setelah uji coba lapangan diperoleh perangkat final. Perangkat final pada tahap develop, disebarkan pada teman sejawat melalui forum MGMP dan dipublikasikan dalam blog pribadi peneliti pada tahapan disseminate.

Teknik pengumpulan data dalam penelitian ini ada dua macam, yaitu teknik tes dan non tes. Teknik tes, diberikan melalui TKPM, sedangkan teknik nontes dilakukan melalui pemberian angket motivasi. Instrumen penelitian yang dikembangkan dalam penelitian ini adalah lembar validasi perangkat pembelajaran dan angket pengukur motivasi siswa. Instrumen penelitian yang dikembangkan dibuat berdasarkan teori yang ada disesuaikan dengan pembelajaran dengan pendekatan IDEAL berbantuan GeoGebra. Instrumen penilaian yang dibuat dikonsultasikan terlebih dulu dengan ahli sehingga instrumen yang digunakan untuk menilai perangkat valid oleh penilaian ahli. Data tentang motivasi siswa, dan hasil validasi perangkat pembelajaran yang diperoleh digunakan sebagai dasar untuk merevisi perangkat pembelajaran. 
Instrumen Lembar Validasi Perangkat Pembelajaran digunakan untuk validasi silabus, RPP, dan LKS yang meliputi 4 komponen yakni petunjuk, aspek-aspek yang dinilai, saran dan kesimpulan hasil penilaian secara umum. Penilaian pada silabus, RPP, dan LKS dengan skala penilaian rating scale (Sugiyono, 2010: p.141), validator ahli memilih salah satu dari jawaban kuantitatif yang disediakan. Arti dari jawaban kuantitatif tersebut dijelaskan tersendiri dalam pedoman penskoran validasi silabus, RPP, dan LKS.

Angket pengukur motivasi siswa digunakan untuk memperoleh data tentang seberapa besar motivasi siswa dalam mengikuti setiap pembelajaran yang direncanakan. Indikator angket pengukur motivasi siswa adalah (1) adanya kepuasan dalam belajar, (2) adanya ketertarikan dan kebutuhan dalam belajar, (3) adanya tantangan dan harapan masa depan, (4) adanya penghargaan dalam belajar, (5) adanya kegiatan yang menarik dalam belajar, dan (6) adanya lingkungan belajar yang mendukung sehingga memungkinkan siswa belajar lebih baik.

Perangkat pembelajaran yang sudah divalidasi ahli selanjutnya dianalisis secara deskriptif atau kualitatif. Hasil validasi berupa penilaian umum yang meliputi layak digunakan tanpa revisi, layak digunakan dengan revisi sesuai saran yang diberikan, maupun tidak layak digunakan.

Adapun langkah-langkah yang digunakan untuk memenuhi kriteria kualitas terhadap produk yang dikembangkan adalah data berupa skor ahli/praktisi yang diperoleh melalui lembar validasi dijumlahkan, kemudian total skor aktual yang diperoleh dikonversikan menjadi data kualitatif skala lima seperti ditunjukkan pada Tabel 1.

Tabel 1.Konversi Data Kuantitatif ke Kualitatif dengan Skala Lima

\begin{tabular}{cc}
\hline Interval & Kriteria \\
\hline $\mathrm{X}>\bar{x}_{\mathrm{i}}+1,5 \mathrm{SB}_{\mathrm{i}}$ & Sangat valid \\
$\bar{x}_{\mathrm{i}}+\mathrm{SB}_{\mathrm{i}}<\mathrm{X} \leq \bar{x}_{\mathrm{i}}+1,5 \mathrm{SB}_{\mathrm{i}}$ & Valid \\
$\bar{x}_{\mathrm{i}}-0,5 \mathrm{SB}_{\mathrm{i}}<\mathrm{X} \leq \bar{x}_{\mathrm{i}}+\mathrm{SB}_{\mathrm{i}}$ & Cukup valid \\
$\bar{x}_{\mathrm{i}}-1,5 \mathrm{SB}_{\mathrm{i}}<\mathrm{X} \leq \bar{x}_{\mathrm{i}}-0,5 \mathrm{SB}_{\mathrm{i}}$ & Kurang valid \\
$\mathrm{X} \leq \bar{x}_{\mathrm{i}}-1,5 \mathrm{SB}_{\mathrm{i}}$ & Tidak valid \\
\hline
\end{tabular}

(Azwar, 2013: p.163)

Keterangan:

$\bar{x}_{\mathrm{I}}=$ rerata skor ideal

$=1 / 2($ skor maks ideal + skor min ideal $)$

$\mathrm{SB}_{\mathrm{i}}=$ Simpangan baku ideal

$=\frac{1}{6}($ skor maks ideal - skor min ideal $)$

$\mathrm{X}=$ Total skor aktual
Penilaian guru sebagai praktisi dan pengguna diberikan sebelum perangkat diujicobakan di lapangan. Perangkat yang dinilai meliputi silabus, RPP, LKS, dan aplikasi software GeoGebra. Data yang diperoleh berupa lima kategori tanggapan yaitu tidak baik (skor 1), kurang baik (skor 2), cukup (skor 3), baik (skor 4), dan sangat baik (skor 5). Kriteria penilaian guru dikonversikan untuk mendapatkan data kepraktisan perangkat yang dikembangkan. Perangkat yang dikembangkan dikatakan praktis jika penilaian yang dilakukan guru terhadap perangkat minimal dalam kategori praktis.

Uji keterbacaan siswa dilakukan untuk mengetahui daya tangkap dan kemampuan siswa dalam membaca perangkat sebagai subjek penelitian. Uji keterbacaan ini dilakukan terhadap LKS dan pemanfaatan software GeoGebra dalam pembelajaran. Skor keterbacaan siswa terhadap LKS dan pemanfaatan aplikasi software GeoGebra dikonversikan untuk mendapatkan kriteria kepraktisan dari sudut pandang siswa. Perangkat pengembangan dikatakan praktis bagi siswa jika kriteria yang diperoleh minimal dalam kategori praktis.

Tingkat keefektifan pembelajaran dalam penelitian ini, ditinjau dari prestasi dan motivasi belajar matematika siswa. Prestasi belajar siswa diukur dengan pemberian tes kemampuan pemecahan masalah (TKPM). Pembelajaran dikatakan efektif jika 80\% siswa (klasikal) mencapai kriteria ketuntasan minimal 75. Data yang diperoleh dari angket motivasi dianalisis dan dikonversikan hasilnya untuk memperoleh kriteria tingkat motivasi siswa. Pembelajaran dikatakan efektif jika motivasi belajar matematika siswa minimal pada kategori tinggi dicapai oleh $75 \%$ siswa.

Bukti validitas untuk instrumen tes kemampuan penyelesaian masalah (TKPM) dan angket motivasi diperoleh melalui validitas isi. Validitas isi diperoleh melalui analisis rasional yang dilakukan terhadap isi berdasarkan penilaian subjektif (Allen \& Yen, 1979: p.95).

Validitas isi yang digunakan dalam penelitian ini adalah validitas logis atau disebut juga sebagai validitas sampling (sampling validity). Validitas tipe ini menunjuk pada sejauhmana isi alat ukur merupakan representasi dari aspek yang hendak diukur. Suatu alat ukur hendaknya harus dibatasi terlebih dahulu kawasan perilakunya secara seksama dan konkrit (Allen \& Yen, 1979: p.96).

Instrumen TKPM yang digunakan dalam penelitian ini juga valid untuk setiap butirnya. 
Demikian juga dengan instrumen angket motivasi yang menurut ahli memenuhi kriteria valid dan layak digunakan dalam penelitian ini.

Penelitian ini menggunakan rumus koefisien $\alpha$ untuk menentukan estimasi reliabilitas. Koefisien $\alpha$ yang tinggi mengakibatkan reliabilitas tes akan lebih tinggi, demikian pula sebaliknya, jika koefisien $\alpha$ rendah maka reliabilitas tes adalah rendah (Allen \& Yen, 1979: p.83). Selanjutkan akan ditentukan nilai standart error measurement (SEM) yaitu standar deviasi skor eror untuk pengujian tertentu pada pengulangan tes independen dengan tes yang sama atau paralel (Allen \& Yen, 1979: p.90).

Instrumen TKPM dan angket motivasi yang telah diujicobakan terhadap subjek penelitian ini mempunyai koefisien reliabilitas berturut-turut 0,88 dan 0,86 . Hal ini menunjukkan bahwa instrumen TKPM dan angket motivasi yang digunakan untuk mengukur keefektifan pengembangan perangkat sangat reliabel. Adapun SEM untuk instrumen TKPM adalah sebesar 6,71 dan SEM untuk instrumen angket motivasi adalah 4,25 .

Pengujian hipotesis dilakukan dengan menggunakan uji proporsi untuk menentukan apakah ketercapaian KKM secara klasikal sudah terpenuhi. Keefektifan perangkat yang dikembangkan dari prestasi belajar siswa adalah jika paling sedikit $80 \%$ siswa berhasil mencapai nilai minimal 75.

Langkah pertama yang dilakukan adalah dengan menentukan hipotesis yang akan diuji, yaitu:

Ho: siswa yang memperoleh nilai minimal 75 paling sedikit $80 \%$;

Ha: siswa yang memperoleh nilai minimal 75 kurang dari $80 \%$.

Selanjutnya dihitung menggunakan statistik uji $z=\frac{\frac{x}{n}-\mu_{0}}{s / \sqrt{n}}$, dengan $n$ menyatakan banyaknya siswa, $\mu_{o}$ adalah nilai yang sudah diketahui (80\%), dan $s$ adalah simpangan baku dari populasi, serta $x$ adalah banyaknya siswa yang nilainya mencapai atau melebihi KKM. Kriteria keputusan yang digunakan dalam uji hipotesis ini adalah Ho ditolak jika $z_{\text {hitung }}<-z_{\propto}$ dengan $\propto=5 \%$.

Pengujian hipotesis untuk mengetahui keefektifan perangkat yang dikembangkan dari motivasi belajar siswa adalah uji proporsi. Perangkat yang dikembangkan dikatakan efektif dari motivasi belajar siswa adalah jika paling sedikit $75 \%$ siswa memiliki motivasi belajar tinggi. Hipotesis yang akan diuji adalah sebagai berikut.

Ho: minimal $75 \%$ siswa mempunyai motivasi belajar yang tinggi;

Ha: kurang dari $75 \%$ siswa mempunyai motivasi belajar yang tinggi.

Selanjutnya dihitung menggunakan statistik uji $z=\frac{\frac{\frac{x}{n}-\mu_{0}}{s / \sqrt{n}}}{s}$ dengan $n$ menyatakan banyaknya siswa, $\mu_{o}$ adalah nilai yang sudah diketahui (75\%), dan $s$ adalah simpangan baku dari populasi, serta $x$ adalah banyaknya siswa yang minimal mempunyai motivasi belajar tinggi. Kriteria keputusan yang digunakan dalam uji hipotesis ini adalah Ho ditolak jika $z_{\text {hitung }}<-z_{\infty}$ dengan $\propto=5 \%$.

\section{HASIL DAN PEMBAHASAN}

\section{Data Hasil Validasi Ahli}

Pengembangan produk ini melalui dua tahap validasi. Validasi pertama dilakukan terhadap lembar validasi perangkat yang akan digunakan validator dan lembar penilaian perangkat pembelajaran yang akan digunakan oleh guru maupun lembar uji keterbacaan perangkat yang akan digunakan oleh siswa. Selanjutnya pada tahap kedua, dilakukan validasi terhadap perangkat pembelajaran, penggunaan software GeoGebra, dan instrumen keefektifan pembelajaran yang berupa TKPM dan angket motivasi. Validasi dilakukan oleh tiga orang validator dari kalangan dosen Matematika UNY. Validator 1 memvalidasi lembar validasi. Perangkat pembelajaran yang berupa silabus, RPP, dan LKS divalidasi oleh validator 2 dan validator 3 . Sedangkan soal TKPM dan angket motivasi divalidasi oleh ketiga validator tersebut.

Selama proses validasi lembar validasi, saran dan masukan dari validator, digunakan peneliti untuk merevisi lembar validasi yang akan digunakan. Setelah revisi dilakukan dan lembar validasi perangkat untuk validator termasuk lembar validasi angket motivasi dan soal TKPM dinyatakan valid, maka lembar validasi baru dapat digunakan oleh validator lainnya. Demikian juga dengan lembar penilaian guru terhadap perangkat pembelajaran, baru dapat digunakan oleh guru sebagai penilai, jika sudah memenuhi kriteria valid oleh validator 1 . Data yang diperoleh, menunjukkan bahwa lembar validasi yang akan digunakan untuk memvalidasi 
perangkat oleh validator lain dinyatakan valid. Demikian juga dengan lembar penilaian guru terhadap perangkat pembelajaran yang dihasilkan maupun lembar validasi TKPM dan angket motivasi.

Lembar validasi silabus yang valid menghasilkan delapan indikator validasi silabus, yang selanjutnya dijabarkan menjadi 23 butir pernyataan. Skor validasi silabus oleh kedua validator masing-masing 99 yang jika dikonversikan masuk dalam kriteria sangat valid.

Oleh karena itu, silabus yang dikembangkan sudah layak digunakan untuk diujicobakan. Hasil dari proses validasi lembar validasi RPP adalah delapan aspek yang dijabarkan menjadi 37 butir pernyataan. Hasil validasi menunjukkan bahwa RPP yang dihasilkan memenuhi kriteria sangat valid. Demikian juga dalam validasi lembar validasi LKS, menghasilkan delapan aspek yang dijabarkan ke dalam 18 butir. LKS yang dikembangkan dinilai sangat valid oleh validator 2 dan validator 3. Secara umum, dapat disimpulkan bahwa silabus dan RPP yang dikembangkan, menurut validator memenuhi kriteria sangat valid. Hal ini dapat terjadi, dalam proses pengembangan silabus dan RPP, peneliti menggunakan acuan Permendiknas No. 41 tahun 2007 dan juga Permendikbud No. 65 Tahun 2013. Hasil validasi RPP oleh kedua validator adalah 169 (sangat valid) dan 162 (sangat valid), sedangkan validasi LKS adalah 79 dan 74 yang juga masuk dalam kriteria sangat valid.

Selanjutnya, validasi terhadap soal TKPM dan angket motivasi dilakukan oleh ketiga validator. Soal TKPM yang terdiri atas delapan butir semuanya dinyatakan valid oleh ketiga validator. Namun demikian, ada beberapa revisi yang dilakukan sesuai saran ketiga validator. Demikian juga dengan angket motivasi yang terdiri atas 25 butir pernyataan. Meskipun semuanya dinyatakan valid, namun perlu ada beberapa perubahan redaksi bahasa yang digunakan dalam setiap butir pernyataan, sehingga lebih mudah dipahami karena tidak menimbulkan penafsiran ganda.

\section{Data Hasil Uji Coba Terbatas}

Uji coba terbatas dilakukan terhadap sepuluh orang siswa kelas IX yang dipilih secara acak dengan rincian tiga orang siswa memiliki kemampuan tinggi, empat orang siswa berkemampuan sedang, dan sisanya berkemampuan rendah. Hal ini sesuai dengan yang dikemukakan oleh Thiagarajan, Semmel, \& Semmel (1974: p.138), bahwa pada tahap pengujian awal (uji coba terbatas) dilakukan oleh sekelompok siswa terpilih, yang diminta untuk memberikan respon dan komentar tentang produk yang dikembangkan. Kesepuluh orang siswa tersebut diminta untuk membaca LKS dan diberi kesempatan untuk menggunakan aplikasi software GeoGebra yang telah dikembangkan. Selanjutnya, kesepuluh siswa tersebut diminta untuk mengisi angket uji keterbacaan untuk mengetahui respon dan komentar siswa. Kesepuluh responden tersebut menyatakan bahwa LKS dan aplikasi GeoGebra yang dikembangkan memenuhi kriteria sangat praktis. Hal ini menunjukkan bahwa secara umum LKS dan aplikasi GeoGebra yang dikembangkan sudah bisa digunakan dalam uji lapangan.

\section{Data Hasil Uji Coba Lapangan}

Uji coba lapangan dilaksanakan untuk mengetahui tingkat kepraktisan dan keefektifan produk yang dikembangkan hasil dari uji coba terbatas. Tingkat kepraktisan produk yang dikembangkan dilihat berdasarkan analisis data tentang penilaian guru, penilaian siswa, dan hasil observasi keterlaksanaan pembelajaran yang telah dilakukan. Sementara itu, tingkat keefektifan produk yang dikembangkan dilihat berdasarkan hasil analisis data tentang TKPM dan angket motivasi yang diberikan di akhir rangkaian pembelajaran materi Teorema Pythagoras.

Penilaian oleh guru dilakukan terhadap perangkat pembelajaran yang meliputi silabus, RPP, LKS, dan pemanfaatan software GeoGebra dalam pembelajaran. Penilaian yang dilakukan dimaksudkan untuk mengetahui tingkat kepraktisan perangkat pembelajaran yang dikembangkan. Penilaian ini dilakukan oleh dua orang guru, yaitu guru yang melakukan pembelajaran dengan menggunakan perangkat yang dikembangkan dan guru yang mengamati (mengobservasi) keterlaksanaan pembelajaran dengan perangkat yang dikembangkan. Hasil penilaian guru terhadap perangkat yang dikembangkan adalah 123 dan 114 yang berada pada kategori sangat praktis.

Oleh karena itu, dapat disimpulkan bahwa perangkat pembelajaran yang dikembangkan jika digunakan dalam pembelajaran termasuk dalam kategori sangat praktis. Namun produk yang dikembangkan masih perlu perbaikan sesuai dengan saran yang diberikan oleh guru penilai dalam uji coba lapangan.

Penilaian yang dilakukan oleh siswa diberikan setelah keseluruhan proses pembelajaran 
materi Teorema Pythagoras berakhir. Penilaian dilakukan terhadap LKS dan penggunaan aplikasi software GeoGebra. Rata-rata penilaian siswa terhadap produk tersebut adalah praktis. Rincian hasil penilaian siswa dapat dilihat dalam Tabel 2.

Tabel 2. Skor Hasil Penilaian Siswa

\begin{tabular}{lccc}
\hline Kriteria & Skor & $\begin{array}{c}\text { Banyaknya } \\
\text { Siswa }\end{array}$ & Persent \\
\hline SP & $48<\mathrm{x} \leq 60$ & 10 & $42 \%$ \\
P & $40<\mathrm{x} \leq 48$ & 14 & $58 \%$ \\
CP & $32<\mathrm{x} \leq 40$ & 0 & $0 \%$ \\
KP & $24<\mathrm{x} \leq 32$ & 0 & $0 \%$ \\
TP & $12 \leq \mathrm{x} \leq 24$ & 0 & $0 \%$ \\
\hline
\end{tabular}

Ket: SP (sangat praktis), P(praktis), CP(cukup praktis), KP(kurang praktis), TP(tidak praktis).

Berdasarkan data dalam tabel 1, dapat disimpulkan bahwa hasil penilaian siswa terhadap produk yang dikembangkan termasuk dalam kategori praktis dan sangat praktis. Jadi secara umum, produk yang dikembangkan dapat digunakan secara praktis oleh siswa.

Proses berlangsungnya pembelajaran diamati oleh seorang observer, yaitu seorang guru matematika kelas VII. Sedangkan guru yang melaksanakan uji coba adalah guru matematika kelas VIII yang digunakan sebagai uji coba. Hasil pengamatan yang diperoleh terhadap proses keterlaksanaan pembelajaran adalah bahwa kegiatan guru yang dilakukan pada umumnya sudah sesuai dengan kegiatan yang direncanakan dalam RPP. Demikian juga dengan aktivitas siswa. Kegiatan siswa secara rinci dapat diamati dari LKS siswa selam enam pertemuan. Siswa sudah berusaha menyelesaikan permasalahan yang disajikan dengan pendekatan IDEAL.

TKPM yang diberikan di akhir proses pembelajaran bertujuan untuk mengetahui keefektifan produk yang dikembangkan ditinjau dari prestasi belajar siswa. Kriteria minimum yang ditetapkan adalah minimal $80 \%$ siswa memperoleh nilai TKPM lebih dari atau sama dengan 75. Secara rinci perolehan hasil penilaian TKPM dapat dilihat dalam Tabel 3.

Tabel 3. Hasil Penilaian TKPM

\begin{tabular}{lccc}
\hline $\begin{array}{c}\text { Interval } \\
\text { nilai }\end{array}$ & Kriteria & $\begin{array}{c}\text { Banyaknya } \\
\text { siswa }\end{array}$ & Persentase \\
\hline$x>75$ & Terlampaui & 14 & $58,3 \%$ \\
$x=75$ & Tercapai & 6 & $25 \%$ \\
$x<75$ & Belum & 4 & $16,67 \%$ \\
\hline
\end{tabular}

Data dalam tabel tersebut menunjukkan bahwa $25 \%$ siswa dapat mencapai KKM dan
58,3\% siswa berhasil melampaui KKM. Jadi secara umum dapat disimpulkan bahwa lebih dari $80 \%$ siswa, yaitu $83,3 \%$ siswa berhasil mencapai kriteria minimum yang ditetapkan. Sehingga produk yang dikembangkan sudah memenuhi kriteria efektif ditinjau dari prestasi belajar siswa.

Angket motivasi yang diberikan kepada siswa ditujukan untuk mengetahui keefektifan produk yang dikembangkan. Kriteria keefektifan produk dilihat dari motivasi siswa adalah minimal $75 \%$ siswa mempunyai motivasi belajar Matematika yang tinggi. Rincian hasil skor angket motivasi dapat diamati pada Tabel 4.

Tabel 4. Skor Angket Motivasi Belajar Matematika Siswa

\begin{tabular}{cccc}
\hline Kriteria & Skor & $\begin{array}{c}\text { Banyak } \\
\text { Siswa }\end{array}$ & $\begin{array}{c}\text { Persen- } \\
\text { tase }\end{array}$ \\
\hline ST & $100<\mathrm{x} \leq 125$ & 8 & $33,33 \%$ \\
$\mathrm{~T}$ & $83<\mathrm{x} \leq 100$ & 13 & $54,17 \%$ \\
$\mathrm{~S}$ & $67<\mathrm{x} \leq 83$ & 3 & $12,5 \%$ \\
$\mathrm{R}$ & $50<\mathrm{x} \leq 67$ & 0 & $0 \%$ \\
$\mathrm{SR}$ & $25 \leq \mathrm{x} \leq 50$ & 0 & $0 \%$ \\
\hline
\end{tabular}

Ket: ST(sangat tinggi), T(tinggi), S(sedang), $\mathrm{R}$ (rendah), SR(sangat rendah).

Berdasarkan tabel 4, sebanyak delapan siswa $(33,33 \%)$ mempunyai motivasi belajar Matematika yang sangat tinggi dan $54,17 \%$ siswa mempunyai motivasi tinggi dan sisanya mempunyai motivasi sedang. Jadi dapat disimpulkan bahwa sebanyak $87,5 \%$ siswa mempunyai motivasi belajar Matematika dalam kategori tinggi dan sangat tinggi. Oleh karena itu, secara umum dapat disimpulkan bahwa produk yang dikembangkan sudah efektif dilihat dari motivasi belajar Matematika siswa.

\section{Analisis Data Validasi Ahli}

Validasi terhadap produk yang dikembangkan dilakukan oleh ahli, yang berasal dari akademisi dosen matematika UNY. Sebelum digunakan untuk uji coba terbatas maupun uji coba lapangan, produk yang dikembangkan minimal harus memenuhi kriteria valid. Demikian juga dengan instrumen yang akan digunakan untuk mengukur keefektifan produk yang dikembangkan. Produk yang dikembangkan meliputi silabus, RPP, dan LKS. Sedangkan soal TKPM dan angket motivasi merupakan instrumen pendukung untuk mengukur keefektifan produk.

Produk dan instrumen yang dikembangkan dinilai validitasnya dengan menggunakan lembar penilaian validasi produk. Namun sebe- 
lum lembar penilaian validasi produk digunakan, tentunya harus valid. Kevalidan lembar penilaian validasi produk ditentukan oleh validator 1.

Kriteria lembar penilaian validasi terdiri atas tiga aspek, yaitu petunjuk, isi, dan bahasa. Aspek petunjuk terdiri atas dua indikator, yaitu petunjuk pengisian lembar validasi dinyatakan dengan jelas dan kriteria penilaian dinyatakan dengan jelas. Aspek isi terdiri atas tiga indikator, yaitu tujuan penggunaan lembar validasi dirumuskan dengan jelas dan terukur, aspek yang diukur dalam lembar validasi mencakup teori pendukung dan komponen dalam pembelajaran, dan butir-butir yang dinyatakan untuk setiap aspek pada lembar validasi menggunkan kata/ pernyataan/perintah yang menuntut pemberian nilai. Sedangkan aspek bahasa terdiri atas dua indikator, yaitu rumusan aspek dan butir penilaian menggunakan bahasa baku dan tidak menggunakan kata/kalimat yang menimbulkan penafsiran ganda.

Penilaian yang diberikan oleh validator 1 terhadap lembar penilaian validasi silabus, RPP, dan LKS adalah tidak valid pada aspek petunjuk dan valid pada aspek isi dan aspek bahasa. Namun terhadap lembar penilaian validasi TKPM, validasi angket motivasi, dan penilaian guru terhadap perangkat pembelajaran, penilaian bernilai valid terhadap ketiga aspek penilaian. Kesimpulan penilaian secara umum terhadap keseluruhan lembar penilaian validasi adalah bahwa lembar penilaian validasi layak digunakan dengan revisi.

Revisi yang disarankan oleh validator terhadap lembar penilaian validasi berbeda-beda. Komentar dan saran perbaikan terhadap lembar penilaian validasi silabus adalah petunjuk perlu diperbaiki, keterangan skala penilaian perlu diganti, butir ke-16 dijadikan dua, dan butir ke20 sebaiknya dihilangkan. Senada dengan lembar penilaian validasi silabus, lembar penilaian validasi RPP mendapatkan komentar dan saran perbaikan bahwa perlu penggantian keterangan skala penilaian dan butir pertama sebaiknya dipilih salah satu saja. Demikian juga keterangan skala penilaian yang ada pada lembar penilaian validasi LKS. Sedangkan lembar penilaian guru terhadap perangkat pembelajaran perlu adanya perbaikan dalam hal reduksi butir pernyataan yang dirasa bermakna sama, yaitu pada butir 12 dan butir 14, dan juga butir 19 dan butir 20 . Perlu adanya perbaikan dalam menyederhanakan tabel penilaian disarankan validator pada lembar penilaian validasi TKPM dan angket motivasi.

Lembar penilaian validasi yang telah direvisi sesuai saran dan dinyatakan valid oleh validator 1 selanjutnya dapat digunakan oleh validator 2 dan validator 3. Lembar validasi tersebut digunakan untuk menilai kevalidan produk yang dikembangkan beserta instrumen pendukungnya.

Secara keseluruhan, hasil validasi silabus yang dilakukan oleh validator 2 dan validator 3 menunjukkan kriteria sangat valid. Data hasil validasi silabus dianalisis berdasarkan aspekaspek penilaian validasi. Adapun aspek-aspek yang dinilai adalah kelengkapan unsur silabus, pengembangan karakter, materi pembelajaran, pengalaman belajar siswa, indikator pencapaian kompetensi, penilaian, alokasi waktu, dan sumber dan media pembelajaran. Aspek-aspek tersebut disesuaikan dengan komponen pokok dalam pengembangan silabus, yaitu komponen yang berkaitan dengan kompetensi yang hendak dikuasai, komponen yang berkaitan dengan cara menguasai kompetensi, komponen yang berkaitan dengan cara mengetahui pencapaian kompetensi, dan komponen pendukung (Depdiknas, 2008: p.19). Keempat komponen tersebut dapat dijabarkan dalam beberapa aspek, yaitu SK, KD, indikator, materi, kegiatan pembelajaran, teknik penilaian, alokasi waktu, dan sumber belajar.

Hasil validasi silabus tiap aspek penilaian menunjukkan bahwa aspek kelengkapan unsur silabus, materi pembelajaran, pengalaman belajar siswa, indikator pencapaian kompetensi, serta sumber dan media pembelajaran dinyatakan sangat valid oleh validator 2 dan validator 3 . Sedangkan aspek pengembangan karakter, penilaian, dan alokasi waktu memenuhi kriteria valid.

Kesimpulan hasil penilaian silabus secara umum menunjukkan bahwa silabus yang dikembangkan layak digunakan dengan revisi sesuai saran yang diberikan. Adapun saran yang diberikan berupa perbaikan redaksi dan tata tulis pada beberapa bagian naskah silabus.

Hasil validasi RPP secara keseluruhan memenuhi kriteria sangat valid. Analisis validasi dilakukan juga terhadap tiap aspek penilaian RPP. Adapun aspek penilaian yang dimaksud adalah identitas materi pelajaran, rumusan tujuan dan indikator, pemilihan materi, metode pembelajaran, kegiatan pembelajaran, pemilihan sumber dan media pembelajaran, penilaian hasil belajar, dan kebahasaan. Aspek tersebut disesuaikan dengan komponen RPP sebagaimana 
yang tertuang dalam Permendiknas No. 41 Tahun 2007.

Hasil penilaian validasi RPP berdasarkan tiap aspek penilaian menunjukkan kriteria sangat valid. Namun kesimpulan penilaian hasil validasi menunjukkan bahwa RPP yang dikembangkan layak digunakan dengan revisi sesuai saran yang diberikan. Adapun saran dari validator adalah pada KD 3.1, indikatornya tidak ditemukan pemecahan masalah sesuai dengan kompetensi dasar menggunakan Teorema Pythagoras untuk pemecahan masalah. Selain itu, masih perlu adanya perbaikan pada redaksi materi. Oleh karena itu dilakukan revisi sesuai saran untuk memperoleh produk RPP yang lebih baik.

LKS yang dikembangkan dinilai sangat valid oleh validator 2 dan validator 3. Penilaian kevalidan LKS didasarkan pada delapan aspek, yang terdiri atas identitas dan petunjuk, alokasi waktu, tujuan pembelajaran, prosedur kegiatan, tampilan, bahasa, isi, dan pertanyaan/soal.

Berdasarkan delapan aspek pelinilaian validasi, LKS memenuhi kriteria valid dan sangat valid. Kriteria sangat valid terpenuhi dalam aspek identitas dan petunjuk, alokasi waktu, prosedur kegiatan, bahasa, isi, dan pertanyaan/ soal. Sedangkan aspek tujuan pembelajaran dan tampilan memenuhi kriteria valid.

Kesimpulan hasil penilaian terhadap LKS yang dikembangkan adalah layak digunakan dengan revisi sesuai saran yang diberikan. Validator 3 memberikan komentar terlalu banyaknya tulisan/baris dalam setiap halamannya sehingga tampilan LKS terkesan ruwet bisa membuat siswa malas membacanya. Sementara itu validator 2 memberikan komentar bahwa ada beberapa tahapan pengenalan konsep yang belum runtut. Oleh karena itu, dilakukan perbaikan dalam pengenalan konsep yang lebih runtut sesuai materi, dan tampilan LKS perlu dibenahi supaya ada cukup ruang bagi siswa untuk menuliskan kegiatan yang dilakukan.

Tes Kemampuan Penyelesaian Masalah (TKPM) terdiri atas delapan butir pertanyaan yang divalidasi oleh validator 1 , validator 2 , dan validator 3 . Ketiga validator menyatakan bahwa kedelapan butir tersebut valid dan layak digunakan dengan beberapa revisi sesuai saran yang diberikan.

Instrumen TKPM terdiri atas kisi-kisi instrumen TKPM, lembar instrumen TKPM, dan pedoman penyekoran TKPM. Kesimpulan hasil penilaian TKPM oleh ketiga validator adalah layak digunakan dengan revisi sesuai saran yang diberikan. Komentar dan saran perbaikan dari validator 1 adalah: (1) tidak setiap butir soal harus digunakan untuk mengukur ketercapaian indikator TKPM; (2) tuliskan dulu (buat tabel) indikator TKPM dan nomor butirnya; (3) lembar jawaban tidak perlu diberi langkah penyelesaian IDEAL. Sementara itu validator 3 memberikan komentar bahwa perlu adanya perbaikan sesuai saran waktu konsultasi. Menurut validator 3, perlu adanya perbaikan pada redaksi kalimat soal dan gambar pendukung dalam soal.

Angket motivasi dinilai oleh ketiga validator. Kesimpulan hasil penilaian secara umum terhadap angket motivasi ini adalah layak digunakan dengan revisi sesuai saran yang diberikan. Menurut validator 1, semua butir dinyatakan valid dengan beberapa revisi. Saran yang diberikan oleh validator 1 adalah bahwa harus diusahakan ada butir pernyataan yang terkait dengan treatment yang diberikan. Validator 3 menyarankan perlu adanya revisi redaksi pada beberapa butir pernyataan. Demikian juga dengan saran dari validator 2. Saran-saran tersebut ditindak lanjuti dengan mengganti dan memperbaiki redaksi butir pernyataan yang ada.

Uji coba terbatas dilakukan setelah produk yang dikembangkan dinyatakan valid oleh validator ahli. Uji coba terbatas dilakukan terhadap siswa sebagai uji keterbacaan terhadap produk yang dikembangkan. Hasil akhir uji keterbacaan siswa terhadap LKS dan aplikasi software GeoGebra adalah sangat praktis. Responden siswa dalam uji coba terbatas ini terdiri atas siswa dengan beragam kemampuan. Tiga siswa berkemampuan tinggi, 4 siswa berkemampuan sedang, dan 3 siswa berkemampuan rendah, yang dipilih secara acak dari kelas yang sudah pernah mendapatkan materi Teorema Pythagoras. Skor rata-rata uji keterbacaan dari 10 responden siswa ini adalah 52,9 dan termasuk dalam kategori sangat praktis.

Meskipun secara umum, hasil uji keterbacaan siswa ini termasuk dalam kategori sangat praktis, namun hasil uji keterbacaan tiap aspek yang dinilai adalah praktis dan sangat praktis. Kategori praktis dipenuhi oleh produk LKS dan kategori sangat praktis dipenuhi aplikasi software GeoGebra pada materi Teorema Pythagoras.

Analisis uji keterbacaan LKS tiap indikator rata-rata masuk dalam kategori baik. Indikator pertama, kejelasan materi yang ada dalam LKS, menurut responden sudah sangat baik. Responden yang sudah pernah mendapat materi sebelumnya merasa mampu memahami dengan sangat baik terhadap materi yang ada dalam 
LKS. Sementara itu, pada indikator yang kedua, responden beranggapan bahwa kejelasan dan kemudahan memahami bahasa yang digunakan bisa diterima dengan baik. Demikian juga pada indikator yang keempat, responden bisa dengan mudah dalam memahami soal yang ada dalam LKS. Indikator ketiga tentang kemenarikan penampilan LKS, menurut responden masuk dalam kategori menarik.

Secara umum dapat disimpulkan bahwa LKS yang dikembangkan praktis digunakan oleh siswa. Sehingga LKS tersebut layak digunakan dalam uji coba lapangan. Namun, masih perlu ada beberapa perubahan dalam LKS, terutama dalam hal penampilan supaya tampak lebih menarik bagi siswa. Sebagaimana yang diungkapkan oleh Uno (2010: p.27), bahwa hal-hal yang dapat dijadikan penguat belajar merupakan salah satu peranan penting motivasi dalam belajar. Penguat belajar ini, bisa dimunculkan dalam LKS siswa yang dibuat semenarik mungkin, sehingga menarik motivasi belajar siswa.

Secara umum tingkat keterbacaan aplikasi software GeoGebra pada materi Teorema Pythagoras oleh kesepuluh responden tersebut adalah sangat praktis. Indikator uji keterbacaan aplikasi software GeoGebra pada materi Teorema Pythagoras terdiri atas tiga hal, yaitu kemudahan pengadaan software GeoGebra, kemudahan penggunaan/ pengoperasian software GeoGebra, keamanan dan kenyamanan penggunaan software GeoGebra. Kesepuluh responden diberi kesempatan untuk mengoperasikan aplikasi GeoGebra. Selanjutnya responden diminta untuk memberikan komentar atas aplikasi yang telah mereka operasikan dengan mengisi angket uji keterbacaan.

Analisis uji keterbacaan aplikasi software GeoGebra pada materi Teorema Pythagoras tiap indikator masuk dalam kategori sangat baik. Bagi responden, software GeoGebra sangat dengan mudah bisa diperoleh, sangat dengan mudah dioperasikan, dan sangat nyaman serta aman digunakan. Secara umum dapat disimpulkan bahwa aplikasi software GeoGebra pada materi Teorema Pythagoras yang ada sangat praktis digunakan, sehingga aplikasi software GeoGebra pada materi Teorema Pythagoras tersebut layak digunakan dalam uji coba lapangan.

\section{Analisis Data Hasil Uji Coba Lapangan}

Penilaian oleh guru dilakukan terhadap perangkat pembelajaran (silabus, RPP, dan LKS) dan juga pemanfaatan aplikasi software
GeoGebra dalam pembelajaran. Penilaian dilakukan oleh dua orang guru, yaitu guru yang menggunakan perangkat dalam pembelajaran di kelasnya dan guru yang mengobservasi keterlaksanaan pembelajaran. Penilai 1 dan penilai 2 masing-masing menyatakan bahwa perangkat pembelajaran yang dikembangkan sangat praktis digunakan oleh guru dalam pembelajaran di kelas.

Jadi secara umum dapat disimpulkan bahwa silabus yang dikembangkan sangat praktis digunakan oleh guru dalam pembelajaran Teorema Pythagoras. Oleh karena silabus yang dikembangkan memperhatikan prinsip-prinsip ilmiah, relevan dengan materi Teorema Pythagoras, sistematis, bahasa yang digunakan konsisten sehingga mudah dipahami, memadai, aktual dan konstekstual, fleksibel, dan menyeluruh. Sebagaimana yang tertuang dalam Depdiknas (2008: p.16).

RPP yang dikembangkan digunakan oleh guru dalam pembelajaran di dalam kelas. Oleh karena itu guru pengguna dan guru pengamat diminta untuk menilai kepraktisannya. Penjabaran kepraktisan RPP adalah bahwa komponen RPP sangat lengkap, komponen RPP yang ada sangat praktis penggunaannya, rancangan alokasi waktu sesuai dengan tahapan pembelajaran, tahapan pembelajaran sangat jelas, kaidah bahasa Indonesia yang digunakan sangat tepat, dan bahasa yang digunakan sangat mudah dipahami. Hal ini sesuai dengan yang diamanatkan pemerintah, bahwa RPP yang dikembangkan guru harus lengkap dan sistematis agar pembelajaran berlangsung secara interaktif, inspiratif, menyenangkan, menantang, memotivasi siswa untuk berpartisipasi aktif, serta memberikan ruang yang cukup bagi prakarsa, kreativitas, dan kemandirian sesuai dengan bakat, minat, dan perkembangan fisik serta psikologis siswa (Depdiknas, 2007: p.7).

Jadi secara umum dapat disimpulkan bahwa RPP yang dikembangkan sangat praktis digunakan oleh guru dalam pembelajaran Teorema Pythagoras. RPP dapat digunakan oleh guru lain, dan dapat disesuaikan dengan kebutuhan guru dan kondisi siswa yang ada.

Selama pembelajaran berlangsung, kegiatan siswa dilakukan sesuai dengan petunjuk yang ada di LKS. Namun demikian, guru tetap menilai kepraktisan LKS yang digunakan. Kepraktisan LKS dilihat dari beberapa indikator, yaitu kesesuaian isi dengan bahan ajar, pemfasilitasian keterlibatan siswa dalam proses pembelajaran, pemfasilitasian siswa untuk belajar secara 
individual maupun kelompok, kemenarikan penampilan LKS, kejelasan bahasa yang digunakan, dan ketepatan penggunaan kaidah Bahasa Indonesia. Secara umum dapat disimpulkan bahwa LKS yang dikembangkan sangat praktis digunakan oleh guru dalam pembelajaran Teorema Pythagoras.

Aplikasi software GeoGebra yang dikembangkan sebagai alat bantu dalam pembelajaran Teorema Pythagoras, juga dinilai kepraktisan penggunaannya oleh guru. Menurut guru penilai 1 dan guru penilai 2, aplikasi GeoGebra dinilai sangat praktis penggunaannya. Bahwa software GeoGebra yang digunakan sangat mendukung ketercapaian tujuan pembelajaran dan sangat relevan dengan materi yang ada. Hal ini senada dengan hasil penelitian yang dilakukan oleh Iranzo \& Fortuny (2011: p.102), bahwa penggunaan GeoGebra dapat membantu siswa dalam membangun representasi konsep dan pemahaman geometris. Selain itu, pengadaan dan penggunaannya sangat mudah dan sangat sesuai dengan tingkat perkembangan fisik dan intelektual siswa. Di samping itu, juga sangat aman dan nyaman digunakan.

Hasil dari penilaian kepraktisan produk oleh siswa adalah 14 siswa (58\%) menyatakan produk praktis digunakan dan 10 siswa (42\%) merasa produk sangat praktis digunakan. Produk yang dinilai kepraktisannya oleh siswa adalah LKS dan aplikasi software GeoGebra.

Kepraktisan penggunaan LKS oleh siswa ini, muncul dalam kegiatan yang ada di LKS. Permasalahan-permasalahan yang ada di LKS dapat diselesaikan dengan tahapan penyelesaian masalah dengan pendekatan IDEAL. aplikasi GeoGebra yang digunakan dalam pembelajaran Teorema Pythagoras sangat praktis digunakan oleh siswa. Aplikasi ini dapat dikembangkan lebih lanjut untuk pembelajaran materi lain yang relevan. Selama pembelajaran, GeoGebra hanya digunakan sebagai alat bantu, karena siswa juga memahami Teorema Pythagoras secara konseptual secara aljabar maupun yang lain. Konsep dasar dalam membuktikan Teorema Pythagoras secara aljabar mudah diterima oleh siswa, karena sebelumnya siswa sudah mendapatkan materi tentang operasi perkalian aljabar dan juga materi segitiga dan segiempat.

Pengoperasian aplikasi GeoGebra sangat mudah dilakukan oleh siswa. Aplikasi GeoGebra sangat dinamis, sehingga siswa dengan mudah bisa mengekplorasinya secara interaktif. Selanjutnya hasil eksplorasi yang diperoleh, diisikan dalam tabel-tabel yang ada di LKS.
Pada akhirnya siswa bisa menemukan konsep pada materi Teorema Pythagoras. Sebagai contoh pada kegiatan pertemuan pertama, aplikasi GeoGebra digunakan sebagai alat bantu dalam menemukan konsep tentang keberlakuan Teorema Pythagoras pada segitiga siku-siku. Jadi dapat disimpulkan bahwa soft-ware GeoGebra yang digunakan pada materi Teorema Pythagoras sangat aplikatif dan praktis penggunaannya bagi siswa. Hal ini sesuai dengan sebagaimana yang dimaksud dalam penelitiannya Haciomeroglu (2011: p.142), bahwa ilustrasi dinamis dalam GeoGebra memungkinkan siswa untuk memperkaya pemahaman matematis. Senada dengan hal tersebut, Karadag \& Mcdougall (2011: p.176) juga menyatakan bahwa GeoGebra mendukung proses pemahaman, karena adanya beragam fasilitas yang dapat digunakan untuk merepresentasikan objek Matematika. Interaksi siswa dalam kelompok ketika menggunakan GeoGebra juga muncul. Selama pembelajaran, siswa bekerja dalam kelompok, yang masing-masing terdiri atas 3 orang. Setiap kelompok berdiskusi melaksanakan kegiatan dalam LKS dengan bimbingan guru. Hal ini memunculkan interaksi siswa dengan siswa dalam kelompok, siswa dengan siswa antar kelompok, dan siswa dengan guru.

Interaksi antara guru dan siswa di atas terjadi melibatkan kontak fisik siswa dengan siswa, maupun guru dengan siswa. Interaksi ini terjadi saat berlangsungnya diskusi kelompok ketika menemukan konsep dengan memanfaatkan aplikasi GeoGebra. Masing-masing kelompok mengekplorasi aplikasi dan melakukan kegiatan sesuai panduan dalam LKS. Ketika terjadi kesulitan, siswa bisa mendiskusikannya dengan teman dalam satu kelompok maupun antar kelompok. Bila diskusi dengan siswa masih belum menemukan titik temu, maka guru akan memberikan bimbingan. Selanjunya, interaksi juga terjadi dalam setiap pengoperasian aplikasi GeoGebra. Siswa dalam satu kelompok akan berbagi tugas untuk menyelesaikan permasalahan yang ada dalam LKS. Interaksi terjadi ketika secara interaktif siswa menggunakan aplikasi, maka hasilnya dituangkan dalam LKS, yang selanjutnya siswa dapat menemukan konsep yang dimaksud.

\section{Revisi Produk}

Kriteria penilaian pada setiap lembar penilaian validasi perlu diperbaiki dengan menghilangkan kata "format" pada setiap indikator yang ada. Perbaikan ini dilakukan pada seluruh 
lembar penilaian validasi, baik silabus, RPP, LKS, TKPM, angket, maupun lembar penilaian untuk guru.

Draf 1 silabus oleh validator 1 mendapatkan saran perbaikan dalam beberapa hal, yaitu perlu adanya perbaikan petunjuk, khususnya tentang skala penilaian yang perlu diganti. Pada beberapa butir indikator, perlu ada yang diperbaiki, yaitu butir nomor 6 sebaiknya dijadikan dua butir, dan butir nomor 20 dirasa tidak perlu, sehingga sebaiknya dihilangkan. Hasil revisi untuk keterangan skala penilaian pada petunjuk dari yang semula "tidak valid, valid, cukup valid, valid, dan sangat valid" diganti menjadi "tidak baik, kurang baik, cukup, baik, dan sangat baik". Sedangkan butir nomor 6 dari yang semula "kesesuaian materi pembelajaran dengan SK dan KD" direvisi menjadi dua butir, yaitu "kesesuaian materi pembelajaran dengan SK" dan "kesesuaian materi pembelajaran dengan KD".

Seperi halnya lembar validasi silabus, lembar validasi RPP juga perlu direvisi skala penilaian pada petunjuk. Saran tambahan dari validator adalah perlu perbaikan pada butir nomor 1. Berdasarkan saran tersebut maka dilakukan perbaikan pada skala penilaian dan butir nomor 1. Skala penilaian diganti menjadi "tidak baik, kurang baik, cukup, baik, dan sangat baik". Sedangkan butir nomor 1 diubah menjadi "kejelasan identitas mata pelajaran". Lembar validasi LKS menurut validator 1 hanya memerlukan perbaikan pada petunjuk, khususnya tentang keterangan skala penilaian. Perbaikan yang dilakukan sesuai saran validator adalah mengganti keterangan skala penilaian menjadi "tidak baik, kurang baik, cukup, baik, dan sangat baik".

Draf 1 silabus divalidasi oleh validator 2 dan validator 3 . Ada beberapa komentar dan saran perbaikan pada silabus yang dikembangkan. Menurut validator, kisi-kisi lembar validasi perlu ada perbaikan khususnya pada aspek pengembangan karakter.

Saran lain dari validator untuk silabus selanjutnya adalah pada bagian contoh instrumen, baik kompetensi dasar 3.1 maupun kompetensi dasar 3.2. Contoh instrumen pada kompetensi dasar 3.1 nomor 2 perlu perbaikan redaksi. Revisi dilakukan dengan memperbaiki redaksi sesuai saran validator. RPP yang dikembangkan perlu mendapat perbaikan pada beberapa bagian khususnya pada kompetensi dasar 3.1. Indikator pada kompetensi dasar 3.1 perlu perbaikan, dari yang semula dijadikan satu sebaiknya dirinci setiap pertemuannya.
Beberapa hal yang harus diperbaiki pada LKS pertemuan 1 adalah permasalahan, aplikasi GeoGebra yang digunakan siswa, dan tahapan melihat kembali pada kegiatan 1. Kegiatan siswa pada pertemuan 1 pada tahapan bertindak yang menggunakan aplikasi Geo-Gebra perlu dilakukan perbaikan setelah dilakukan uji coba terbatas. Aplikasi GeoGebra yang perlu diperbaiki adalah pada contoh kasus mengidentifikasi segitiga siku-siku dengan ukuran sisi segitiga pertama. Perbaikan yang dilakukan adalah dengan mengubah nama sisi segitiga. Setelah dilakukan uji lapangan, tahapan melihat kembali pada kegiatan 1 ternyata juga perlu perbaikan. Hal ini dilakukan karena banyak siswa yang kurang memahami informasi yang diberikan. Oleh karena itu perlu ditambahkan bahwa $c$ merupakan sisi terpanjang dari segitiga $\mathrm{ABC}$.

Saran yang diberikan pada LKS pertemuan 3 adalah bahwa sebelum masuk ke permasalahan, sebaiknya diberikan pengantar untuk mengenalkan materi triple Pythgaoras ke siswa. Hal ini diperlukan karena pada jenjang sekolah dasar, materi ini belum pernah diberikan. LKS pertemuan 4 dan pertemuan 5 perlu perbaikan kegiatan siswa pada tahapan bertindak. Menurut validator, perbaikan yang perlu dilakukan adalah pada bagian mem-bandingkan panjang ketiga sisi segitiga. Sebelumnya contoh yang diberikan, memun-culkan pembanding angka 1 dengan posisi di tengah. Saran validator, sebaiknya pembanding angka 1 dimunculkan pada bagian kiri. Hal ini perlu dilakukan karena akan lebih memudahkan siswa dalam menyederhanakan perbandingan sisi-sisi segitiga istimewa, baik segitiga dengan sudut $45^{\circ}$ maupun segitiga dengan sudut $30^{\circ}$.

Kisi-kisi instrumen sebelumnya hanya memuat tabel kisi-kisi yang berisi kompetensi dasar, indikator pencapaian kompetensi, indikator soal, nomor soal, dan skor maksimal. Oleh validator, sebaiknya diberi tambahan tabel ketercapaian indikator TKPM, karena tidak setiap butir soal bisa digunakan untuk mengukur indikator TKPM. Tabel ketercapaian TKPM tersebut dilengkapi juga dengan nomor butir yang sesuai.

Lembar instrumen TKPM terdiri atas tiga bagian, yaitu petunjuk pengerjaan, soal, dan lembar jawaban. Perbaikan pada petunjuk pengerjaan adalah pada petunjuk ke-3, yang semula "Jawablah setiap pertanyaan dengan jelas dan terperinci dengan menggunakan langkah IDEAL Problem Solving", diperbaiki menjadi "Jawablah setiap pertanyaan dengan jelas dan 
terperinci". Perbaikan dilakukan karena tidak setiap butir soal bisa digunakan untuk mengukur indikator TKPM. Oleh karena itu, siswa diharapkan dapat menyelesaikan dengan lengkap dan jelas. Sementara itu, guru sebagai korektor yang menganalisis setiap langkah jawaban siswa.

Perbaikan lainnya terdapat pada soal TKPM butir ke-2. Perlu perbaikan redaksi pada kalimat soal, dan ilustrasi gambar sebaiknya dihilangkan, karena konteks soal sudah jelas. Sehingga diharapkan siswa mampu membuat abstraksi dalam gambar sesuai konteks yang ada.

Lembar jawaban yang disediakan, semula diberi tahapan langkah-langkah penyelesaian IDEAL. Namun, sesuai saran validator, sebaiknya lembar jawaban tidak perlu diberi langkah. Jadi perbaikan keseluruhan pada lembar instrumen TKPM secara garis besar hanya terdiri atas dua bagian, yaitu kisi-kisi dan lembar soal.

Setelah dilakukan uji coba terbatas, butir soal TKPM nomor 1a juga perlu perbaikan supaya siswa lebih paham maksud dari soal tersebut. Meskipun telah dilakukan pada beberapa butir sebelum digunakan pada uji lapangan, namun setelah dilakukan uji lapangan ternyata juga masih perlu perbaikan pada butir soal TKPM nomor 3a. Semula, berbunyi "tentukan keempat panjang sisi belah ketupat dan panjang diagonal AC", diubah menjadi "tentukan panjang sisi belah ketupat dan panjang diagonal AC". Hal ini perlu dilakukan, karena sebagian siswa menghitung jumlah keempat sisi belah ketupat. Padahal yang dimaksud dari soal 3a adalah panjang sisi belah ketupat.

Seperti halnya instrumen TKPM, instrumen angket motivasi juga divalidasi oleh tiga orang ahli. Ketiga validator memberikan saran perbaikan perlu adanya perbaikan redaksi pada beberapa butir pernyataan. Butir-butir yang perlu direvisi redaksinya adalah butir 15 , butir 16, butir 18, butir 19, dan butir 21 .

Butir 15 perlu direvisi, karena disarankan ada butir pernyataan yang terkait dengan treatment yang diberikan. Oleh karena itu, butir 15 yang semula "saya senang jika pembelajaran Matematika dilakukan juga di luar kelas", diganti menjadi "saya senang dengan pembelajaran Matematika dalam dua minggu terakhir ini”.

Butir 16, butir 18, butir 19, dan butir 21 perlu perbaikan pada susunan redaksi kalimat. Perbaikan yang dilakukan pada keempat butir tersebut berturut-turut menjadi butir-butir berikut. Butir 16 menjadi "jika pekerjaan sudah selesai, saya senang melakukan kesibukan yang mengganggu konsentrasi belajar teman-teman". Butir 18 direvisi menjadi "saya enggan mengikuti pembelajaran Matematika yang sangat sulit saya pelajari". Butir 19 diperbaiki menjadi "saya akan belajar sungguh-sungguh supaya bisa membanggakan orang tua". Butir 21 diubah menjadi "saya kecewa karena tidak mendapatkan nilai ulangan matematika yang baik, sehingga hadiah dari orang tua tidak bisa saya dapatkan.

\section{Kajian Produk Akhir}

Tahapan yang dilakukan dalam pengembangan produk adalah pendefinisian, perancangan desain, pengembangan, dan penyebaran. Analisis awal dilakukan pada tahap pendefinisian, selanjutnya dibuatlah rancangan produk yang akan dikembangkan. Setelah itu, pada tahap pengembangan dilakukan dua kali uji coba, yaitu uji coba terbatas dan uji coba lapangan. Namun sebelum produk diujicobakan, harus melalui proses validasi oleh ahli. Hasil dari validasi ahli, uji coba terbatas, dan uji coba lapangan, yang selanjutnya dilakukan revisi untuk memperbaiki produk, maka dapat disimpulkan bahwa produk yang dikembangkan telah memenuhi kriteria valid, praktis, dan efektif. Produk dikatakan valid, karena telah melalui proses validasi ahli sampai diperoleh hasil yang valid. Kepraktisan produk ditinjau dari praktis menurut siswa dan praktis menurut guru. Sedangkan produk memenuhi kriteria efektif dilihat berdasarkan prestasi belajar siswa dan skor angket motivasi belajar matematika siswa.

Kevalidan perangkat yang meliputi silabus, RPP, dan LKS didasarkan pada kriteria validasi produk hasil pengembangan yang telah ditetapkan. Berdasarkan hasil validasi ahli, diperoleh bahwa produk perangkat pembelajaran yang dikembangkan memenuhi kriteria sangat valid. Instrumen pendukung penelitian yang berupa instrumen TKPM dan instrumen angket motivasi juga dinyatakan sangat valid oleh validator.

Kepraktisan produk ditentukan berdasarkan penilaian guru dan penilaian siswa. Guru yang menilai kepraktisan produk adalah guru pengguna perangkat dan guru observer yang mengamati keterlaksanaan proses pembelajaran. Kedua guru penilai menyatakan bahwa perangkat pembelajaran yang dikembangkan memenuhi kriteria sangat praktis. Berdasarkan data tentang penilaian guru dan penilaian siswa terhadap produk yang dikembangkan, maka 
dapat disimpulkan bahwa perangkat yang dikembangkan memenuhi kriteria praktis.

Produk yang dikembangkan memenuhi kriteria efektif ditinjau dari dua hal, yaitu prestasi belajar siswa dan skor angket motivasi belajar matematika siswa. Prestasi belajar siswa dalam hal ini diukur dengan menggunakan instrumen TKPM materi Teorema Pythagoras. Kriteria keefektifan yang ditetapkan adalah jika $80 \%$ siswa memperoleh nilai di atas KKM sebesar 75. Hasil dari pengerjaan soal TKPM, jika dikalkulasi, siswa yang mampu mencapai nilai minimal KKM adalah 83,3\%. Oleh karena itu, sudah memenuhi kriteria keefektifan yang ditetapkan. Jadi dapat disimpulkan bahwa produk yang dikembangkan sudah memenuhi kriteria efektif ditijau dari prestasi belajar siswa.

Motivasi belajar siswa diukur dengan menggunakan angket motivasi siswa yang diisi oleh siswa di akhir pembelajaran materi Teorema Pythagoras. Kriteria keefektifan yang ditetapkan berdasarkan motivasi belajar matematika siswa adalah minimal $75 \%$ siswa mempunyai motivasi yang tinggi. Hasil yang diperoleh adalah sebanyak $12,5 \%$ siswa mempunyai motivasi sedang, $54,17 \%$ siswa mempunyai motivasi tinggi, dan $33,33 \%$ siswa mempunyai motivasi sangat tinggi. Sebanyak $87,5 \%$ siswa mempunyai motivasi tinggi dan sangat tinggi. Jadi dapat disimpulkan bahwa produk yang dikembangkan memenuhi kriteria efektif ditinjau dari motivasi belajar matematika siswa.

\section{SIMPULAN DAN SARAN}

Berdasarkan kajian teori, hasil penelitian, dan pembahasan maka dapat diperoleh simpulan sebagai berikut: (1) Produk perangkat pembelajaran hasil pengembangan dalam penelitian ini berupa silabus, RPP, dan LKS telah melalui proses validasi oleh ahli dengan kriteria sangat valid. Hasil validasi silabus mencapai rata-rata skor 99 dari skor maksimal 115. Sedangkan rata-rata skor hasil validasi RPP adalah 165 dari skor maksimal 185 dan rata-rata skor hasil validasi LKS adalah 77 dari skor maksimal 90; (2) Kepraktisan produk perangkat pembelajaran yang dikembangkan telah tercapai melalui hasil analisis data penilaian guru dan siswa. Sejumlah $58 \%$ siswa menyatakan bahwa produk yang dikembangkan praktis digunakan dan sisanya merasa bahwa produk yang dikembangkan sangat parktis; (3) Produk perangkat pembelajaran telah memenuhi kriteria efektif ditinjau dari prestasi dan motivasibelajar siswa. Lebih dari $80 \%(83,33 \%)$ siswa berhasil mencapai KKM yang ditetapkan dan lebih dari $75 \%(87,5 \%)$ siswa memiliki motivasi belajar Matematika yang tinggi.

Penelitian pengembangan yang telah dilakukan menghasilkan produk perangkat pembelajaran berupa silabus, RPP, dan LKS pada materi Teorema Pythagoras dengan pendekatan IDEAL berbantuan GeoGebra telah memenuhi kriteria valid, praktis, dan efektif ditinjau dari prestasi dan motivasi belajar matematika siswa. Oleh karena itu, pembelajaran berbantuan GeoGebra dapat dijadikan sebagai alternatif media pembelajaran di kelas khususnya pada materimateri geometri yang lain, untuk meningkatkan prestasi dan motivasi belajar matematika siswa.

Beberapa saran yang dapat peneliti sampaikan untuk peningkatan kualitas pembelajaran Matematika adalah: (1) bagi siswa; aplikasi GeoGebra pada materi Teorema Pythagoras praktis digunakan oleh siswa sebagai alat bantu ajar mandiri di rumah; (2) bagi guru; produk hasil pengembangan yang berupa silabus, RPP, dan LKS bisa digunakan sebagai acuan dalam mengembangkan aplikasi GeoGebra pada materi geometri lainnya; (3) bagi sekolah, sebaiknya memberikan apresiasi dan motivasi kepada para guru yang mengembangkan produk pembelajaran yang berkualitas; (4) bagi pemerintah, disarankan untuk melengkapi fasilitas laboratorium komputer di setiap sekolah, sehingga pemanfaatan aplikasi GeoGebra dapat diterapkan di seluruh sekolah.

\section{DAFTAR PUSTAKA}

Alderman, M. K. (2004). Motivation for achievement, possibilities for teaching and learning. London: Lawrence Erlbaum Associates Publishers.

Allen, M. J. \& Yen, W. M. (1979). Introduction to measurement theory. Monterey, California: Brooks/Cole Publishing Company.

Azwar, S. (2013). Tes prestasi: fungsi pengembangan pengukuran prestasi belajar. Yogyakarta: Pustaka Pelajar.

Bailey, et al. (2006). Mathematics: Application and concepts course 2. New York: Glencoe/McGraw-Hill.

Blum, W., \& M. Niss. (1991). Applied mathematical problem solving, modeling, applications, and links to other subjects: state, trends and issues in mathematics instruction. Educational Studies in Mathematics, 22, 37-68. 
Bransford , J., \& Stein, B.S. (1993). The IDEAL problem solver: A guide for improving thinking, learning, and creativity $\left(2^{\text {nd }}\right.$ ed). New York: W.H. Freeman.

Brookhart, S. (2010). How to assess higherorder thinking skills in your classroom. Alexandria, VA: ASCD.

Chambers, P. (2008). Teaching mathematics. Chennai, New Delhi: C\&M Digitals Ltd.

Depdiknas. (2007). Peraturan Menteri Pendidikan Nasional Nomor 41 Tahun 2007, tentang Standar Proses.

Depdiknas. (2006). Peraturan Menteri Pendidikan Nasional Nomor 22 Tahun 2006, tentang Standar Isi.

Depdiknas. (2008). Panduan umum pengembangan silabus. Direktorat Jenderal Manajemen Pendidikan Dasar dan Menengah.

Gage, N. L., \& Berliner, D. C. (1984). Educational psychology $\left(3^{r d} e d\right)$. Boston, Massachusetts: Houghton Mifflin Company.

Gantert, A. X. (2007). Integrated algebra 1. New York: Amsco School Publications, Inc.

Haciomeroglu, E. S. (2011). Visualization through dynamic GeoGebra illustration. Dalam Lingguo $\mathrm{Bu} \&$ Robert Schoen (Eds), Pathways to Mathematical Understanding Using GeoGebra (pp 133-144). Rotterdam: Sense Publisher.

Henton, J., Baden, R. M., \& Kieren, D. (1979). Problem solving in the classroom. The Family Coordinator, 28, 61-66.

Iranzo, N., \& Fortuny, M. (2011). Influences of GeoGebra on problem solving strategies. Dalam Lingguo $\mathrm{Bu} \&$ Robert Schoen (Eds), Pathways to Mathematical Understanding Using GeoGebra (pp 91103). Rotterdam: Sense Publisher.

Karadag, Z. \& McDougall, D. (2011). GeoGebra as a cognitive tool. Dalam Lingguo $\mathrm{Bu}$ \& Robert Schoen (Eds), Pathways to Mathematical Understanding Using GeoGebra (pp 169-181). Rotterdam: Sense Publisher.

Kirkley, J. (2003). Principles for teaching problem solving. Indiana: Plato Learning Inc. Available http://www.cimm.ucr.ac.cr/rsoluciondep
ro-blemas/PDFs/Kirkley,\%20Jamie.

\%202003.pdf. Diakses tanggal 23

November 2013.

Nunn, G. D. \& McMahan, K. (2000). Ideal problem solving using a collaborative effort for special needs and at-risk students. Education, 121, 305-312.

Polya, G. (2004). How to solve It? ( $2^{\text {nd }}$ ed.). Princeton: Princeton University Press

Posamentier, A. S. \& Krulik, S. (2009). Problem solving in mathematics, grade 3-6: Powerful strategies to deepen understanding. Thousand Oaks, California: Corwin.

Schoenfeld, A. H. (2013). Reflections on problem solving theory and practice. The Mathematics Enthusiast, 10, 9-34.

Schoenfeld, A. H. (1985). Mathematical problem solving. London: Academic Press Inc. Ltd.

Schoenfeld, A. H. (1980). Teaching problemsolving skills. New York: Departement of Mathematics, Hamilton College. Available at Error! Hyperlink reference not valid.. Diakses tanggal 20 Juni 2013.

Schraw, G., Dunkle, M. E., \& Bendixen, L. D. (1995). Cognitive processes in welldefined and ill-defined problem solving. Applied Cognitive Psychology, 9, 523538.

Schunk, D. H. (2012). Teori-teori Pembelajaran: perspektif pendidikan (edisi 6). (Terjemahan Eva Hamdiah \& Rahmat Fajar). Boston, Massachusetts: Pearson Education Inc. (buku asli diterbitkan tahun 2012).

Skemp, R. R. (1971). The psychology of learning mathematics. Ringwood, Victoria: Penguin Books Ltd.

Sugiyono. (2010). Metode penelitian pendidikan pendekatan kualitatif, kuantitatif, dan $R \& D$. Bandung: Alfabeta.

Thiagarajan, S., Semmel, D. S., \& Semmel, M. I. (1974). Instructional development for training teachers of exceptional children: a sourcebook. Washington, DC: Indiana University.

Uno, H. B. (2010). Teori motivasi dan pengukurannya. Jakarta: Bumi aksara. 